Article

\title{
The True Jesus Church and the Bible in Republican China
}

\author{
Pan Zhao
}

School of Philosophy, Wuhan University, Wuhan 430072, China; zhaopan@whu.edu.cn or zhaopan813@gmail.com

Received: 20 November 2019; Accepted: 7 February 2020; Published: 14 February 2020

check for updates

\begin{abstract}
During China's Republican Era (1912-1949), the True Jesus Church, comprising one of the largest indigenous Pentecostal/charismatic churches in China, created a whole set of exclusive salvation doctrines based on its unique biblical interpretation. This paper attempts to illustrate the role that the Bible played in the development of the True Jesus Church (TJC for short) and how its biblical interpretations functioned in the shaping of its exclusive identity based on certain aspects of its charismatic experiences and unique doctrinal system. The founding of the TJC relied upon charismatic experiences, which were regarded as the work of the Holy Spirit to prove the authority of the Church. Doctrinally, the approaches to biblical interpretation employed by TJC leaders were another source of the church's unique identity: The exclusive status the church assigned to itself was evident in its distinct interpretive approaches, as well as in its innovative rituals, especially facedown immersion baptism. Along with various influences of the Pentecostal tradition and the Chinese social context, these hermeneutics were an important reason for the TJC's development as an independent denomination in the Republican era.
\end{abstract}

Keywords: True Jesus Church; the Bible; charismatic experience; Republican Era; Christianity

\section{Introduction}

During the Republican Era of China, the True Jesus Church (zhen yesu jiaohui 真耶稣教会) was a significant Chinese Pentecostal/charismatic church. It was founded in 1917 and grew into a large denomination, setting up chapters across the entire country within thirty years. In 1950, "the True Jesus Church had 12,500 members and more than 1200 churches (including chapters in Singapore, Hong Kong, and Taiwan, etc.)" (1997, p. 341). Insisting upon its exclusive status as the true church, the True Jesus Church (TJC for short) formed a whole set of doctrines with the typical characteristics of Pentecostal/charismatic churches and claimed that its doctrines were all in conformity with biblical teachings.

Previous studies on the TJC have contributed significantly to our understanding of its history, religious experience, and interrelation with Chinese popular religions; some studies have mentioned the role of the Bible in its development. Lian Xi (Lian 2008) traced the history of the TJC in the Republican era. Defining the TJC as a Chinese popular religion, Lian Xi placed its Pentecostal tradition within the context of Chinese nationalism and indigenous beliefs. In China and the True Jesus, Inouye noted that "I find that the early True Jesus Church's popularity stemmed primarily from its cultural acumen in demonstrating how it adhered to the Bible more closely than other contemporary forms of Christianity, including foreign-missionary Christianity" (Inouye 2018a, p. 88). In another paper, she argued that an appeal to the Bible was an effective way for charismatic Churches to be free of Western theological or cultural traditions (Inouye 2016). She also presented a thorough examination of how Bernt Berntsen and Wei Baoluo engaged in a search for charismatic experiences, in which adhering to the Bible was used to shape their doctrine (Inouye 2018b). Inouye rightly pointed out that the Bible 
played a significant role in the TJC. None of these studies, however, has shed much light on how the TJC concretely harnesses its biblical interpretation to develop its own doctrinal system, an aspect which significantly contributed to its success and popularity. In the field of western Pentecostal hermeneutics, several scholars have illustrated early Pentecostal biblical interpretive approaches. Archer summarized this approach as "the Bible Reading Method", which focused on proving the Pentecostal doctrines of Spirit baptism and the Oneness of God (Archer 2005). Oliverio asserted that there are four interpretive assumptions of early Pentecostals, including the sole authority of the Bible, the restorationist beliefs, the four-five-fold "full-gospel", and a pragmatic naïve realism (Oliverio 2012, pp. 31-32). These studies have contributed to our understanding of the hermeneutics of the TJC; however, the methods they summarized cannot cover all the interpretive approaches of the TJC, which formed its own doctrinal system.

My argument is that the Bible played an important role in the development of the doctrinal system and practices of the TJC, providing the authoritative basis for its exclusive salvation confined within the TJC. The biblical interpretation established unique doctrines that differentiated the TJC from other faith communities; it also shaped the identity of the TJC as an indigenous Chinese church. I will first discuss the relationship between charismatic experience and the Bible for the TJC and determine what doctrines distinguish the TJC from other communities of faith, shaping it into an independent denomination. In the next two sections, I will separately analyze the interpretive methods used to prove their unique doctrines. The literature resources of this study are mainly taken from the publications of the TJC. Besides the articles directly dealing with the biblical interpretations of the Church, the doctrinal arguments supplying the biblical verses as references are also significant resources for this study.

\section{The Pentecostal Experience and the Bible}

In 1901, after Charles Fox Parham taught the gift of the Holy Spirit marked by glossolalia in Topeka, Kansas, his students claimed that they had received this gift. This event is viewed as the beginning of the Pentecostal movement. It was followed in 1907 by the famous Azusa Street revival. The Pentecostal movement was spread to China by missionaries not long after its birth in North America. Bernt Berntsen (贲德新), a Norwegian American missionary deeply influenced by the Azusa Street revival, founded a Pentecostal Mission Apostolic Faith Church that had a great impact on Wei Baoluo (Paul Wei[1] Several believers changed their names after joining the True Jesus Church; they kept their family name and changed their given name to the name of a biblical character. Wei's former name was Wei Enbo, and he took on a biblical name, as did Isaac Wei, John Jiang, Thomas Guo, etc.魏保罗, originally named Wei Enbo 魏恩波), the founder of the TJC. Wei was a silk merchant in Beijing and was converted by the London Missionary Society in 1903. In 1915, Wei was introduced to Berntsen's congregation and was attracted by Berntsen's personality and Pentecostal teachings.[2] Inouye offered a detailed exploration of the whole process by which Berntsen started his mission in China and his friendship with Wei.After he and his daughter were healed through prayer, he joined the Apostolic Faith Church and zealously sought charismatic experiences.

In 1917, Wei claimed that God had appeared and instructed him to be baptized face-down in the river and had revealed to him that his mission was "to correct the Church" (Wei 1947b, p. B18), which meant building a true church in order to correct erring Christian churches all throughout the world. After being called, Wei parted from Berntsen and closed his business to start preaching the gospel on his own and begin his new church.

Many historical documents have recorded the charismatic miracles that happened during the inception of the TJC. When Wei was preaching in Shandong, "he was like a magnet endowed with a tremendous power of attraction, attracting all believers together every day, and the Holy Spirit descended and gave them gifts" (Wei 1947c, p. C8). Many chapters in different provinces also claimed that they had experienced miraculous signs. In the record of church history, it was reported that some people were healed after extensive illnesses; a speech-impaired man suddenly spoke after being 
exorcised (Wei 1947c, p. C9); and a church in Tianjin was built by a doctor, who was inspired to accept the TJC in his dream (Wei 1947c, p. C7). When Gao Daling (高大龄) preached in Shandong in 1920, "wonders, glossolalia, prophecy, healing, exorcism, stigmata, the visions, and the spiritual songs-all these things happened" (Wei 1947c, p. C8). The TJC was developed in tandem with these charismatic signs.

Miraculous experiences were significant for the TJC not only because they inspired its followers, but also because they were understood as the visible, persuasive evidence of the true church, paralleling the miraculous signs recorded in the Bible. "Speaking in tongues", although recorded before the beginning of the Pentecostal movement (Inouye 2018a, p. 67), was connected with the baptism of the Holy Spirit during this time and "the baptism - tongues experience formed a third distinct event in the order of salvation (following conversion and sanctification)" (Wacker 2001, p. 6). When a believer received the baptism of the Holy Spirit as a crucial manifestation of being a Christian, he/she had to speak in tongues as the visible, apparent evidence of this manifestation, which was the symbol of the Holy Spirit's coming during the apostolic ages, which had now reoccurred. For the TJC, this experience was confined to its Church: "The Spirit of Jesus Christ, only descending on our church in the last days, gives spiritual understanding (linggan 灵感), spiritual baptism and the spiritual seal through the laying on of the pastor's hands" (Wei 1947c, p. B3). The believers were also convinced that Jesus had given them authority to perform miracles in the sight of all his true disciples; miracles similar to those Jesus performed in the Gospels also occurred in the TJC and were an overwhelming testimony of the authority of the Church. This is why the TJC viewed the ability to perform miraculous deeds as "the capital of the church" and that "the church could not grow without it" (Wei 1947c, p. N1). In a word, the Bible confirmed the legitimacy of these miraculous signs as the work of the Holy Spirit to identify the Church as the true church blessed by the Holy Spirit: "They lived in a world in which the narratives and promises of the biblical text could play out in everyday life. Over this world, the Holy Spirit swept like a wind, giving them assurance of salvation and power" (Inouye 2018a, p. 118).

However, all types of charismatic experiences, including glossolalia, healing, and exorcism, were not confined to the TJC; they were common features of the Pentecostal churches not only in China but also in other countries. Even though such experiences were seen as confirming that the TJC was the "true church", they were not enough to establish the TJC as the one true church that could "correct" others; this would require developing a doctrinal system.

\section{The Doctrines and the Bible}

Not long after the Church was founded, the leaders realized the significance of biblical studies and theological education for building a strong church, since miracles and wonders were not sufficient. According to church records, some churches were corrupted in the midst of the Hebei chapter in 1923, "they stressed the miraculous signs too much and neglected biblical knowledge" (Wei 1947c, p. G2). Therefore, Wei Yisa (Issac Wei 魏以撒, the son of Wei Baoluo and the leader of the Church after Wei Baoluo's death in 1919) established the first seminary, the "Truth and Holy Spirit Seminary", in Tianjin in 1924. The name of this seminary indicated that it "not only focused on the charismatic gifts, but also stressed the truth, since the Holy Spirit is the truth, and the compilation of the truth is the Bible" (Wei 1947c, p. G2). By 1947, the TJC had built seminaries in eight provinces in China, and the core curriculum included classes on "the Mystery of the Four Gospels, Revelation, and Prophecies of the Prophets" (Wei 1947c, p. G3). This showcased the TJC's emphasis on biblical studies and theological education.

The formation of the doctrines of the TJC had a close relationship with the North American Pentecostal Movement. The leaders then systematized the church's doctrines and practices: The church believed that it was being filled with the "latter rain of the Holy Spirit" marked by glossolalia, the Oneness of God that rejected the doctrine of the trinity, the baptism of the Holy Spirit, facedown immersion baptism, Sabbath-keeping, foot-washing, and so on. Most of the doctrines of the TJC had an affinity with the western Pentecostal traditions that were transmitted by Berntsen, who once played 
an important role as a mediator between western Pentecostals and the Chinese church, which reflects the role that "the development of global transportation technology" (Inouye 2018a, p. 85) played in the Chinese charismatic movement at the beginning of the twentieth century. Berntsen embraced basic Pentecostal ideals, including the gift of the Holy Spirit marked by the gift of tongues, Sabbath-keeping (Inouye 2018a, p. 67), foot-washing, and immersion baptism (Inouye 2018b, pp. 63-64). He also accepted Oneness Pentecostals, having emerged in North America in the 1910s (Wacker 2001, p. 7); after learning this teaching through other Pentecostal publications, he published an article entitled "One Must Be Baptized in the Name of Jesus Christ" (Inouye 2018b, p. 56). All these doctrines were learned by Wei when he was a congregant of the Apostolic Faith Church. Behind these concrete teachings was the idea that the biblical text, especially Acts, should be read and practiced literally as a blueprint since "God had expressed His will with clarity in the apostolic age ... then twentieth-century Christians were obliged to fashion their own lives according to that blueprint" (Wacker 2001, p. 71). The early Pentecostal belief in the Scripture also became the core theological resource for the biblical interpretation of the TJC.

What features shaped the TJC's development as a distinctive denomination in China, since many of its doctrines were not that different from those of other Pentecostal churches? My answer is that the identity of the TJC was founded on two innovative doctrines: One is that the TLC is the only true church, with the mission of correcting all the other churches; the other is that it promises exclusive salvation through facedown immersion baptism. These two beliefs were also the two crucial commandments that Wei claimed to have received from God in his calling vision in 1917. These two beliefs set the TJC apart from other Pentecostal churches of the period. Moreover, claiming itself to be the only true church and creating a new ritual process was not an easy task and exposed the TJC leadership to suspicions of promoting heresy; the validity of their beliefs could only be proven by appealing to a higher authority: the Bible.

Appealing to the Bible for the validity of its doctrines necessitated the doctrine of biblical authority, which formed an important component of TJC doctrine. Among the TJC's "Twelve Fundamental Dogmas", the second read: "the Bible, including the Old Testament and the New Testament is the only scripture to testify to the truth," and "neither other religious scriptures nor writings are sufficient to substantiate truth" (Wei 1947c, p. B2). Only the Bible is the foundation of Christianity. Regarding this biblical reading approach, Guo Ziyan (郭子严), a leader of the TJC, noted that "we must respect the authority of the Bible, which is the inerrant standard of the truth when we read it. It cannot be interpreted in a private way or explained arbitrarily... All the sermons of other denominations or individuals should be examined through the lens of Scripture in order to tell whether they are true or not" (Guo 1947b, p. B2). Jiang Yuehan (John Jiang 蒋约翰) suggested that the "true preacher will never dare to follow his/her own will to interpret the Bible, but rather follow the guidance of the Holy Spirit in handling the word of truth correctly" (Jiang 1950b, p. 106). The TJC also pointed out that the Bible is the supreme standard for formulating the regulations governing Church conferences: "No matter how many people attend the conference, we must obey the biblical teachings; in other words, to avoid one or two people's preaching distorting the true meaning, we gather the majority of members who have deep spiritual wisdom to discuss and study the Holy words in conformity of the truth in order to formulate the regulations" (Wei 1947c, p. D1). In the TJC's doctrinal and theological writings, the authors usually quote many biblical verses to demonstrate the biblical roots of their points, and some works even supply biblical verses' numbers as references after nearly every sentence.

Appealing to biblical authority did not only originate from theological considerations, but also had an affinity with the church's social context, especially nationalism.[3] Although Wei Baoluo once opposed nationalism and suggested that it would become a form of idolatry (Inouye 2018a, p. 108), as the Church developed, it took advantage of nationalism to fight against western denominations and attract Chinese sympathies. One leader claimed that "we do not permit the western people to control the church, and we will eradicate the nature of Chinese people that is dependent on the west and recover the original doctrine of Christianity completely" (Wei 1947c, p. AZ10). The Bible, then, 
became the most important source through which the TJC attempted to recover the "original doctrine of Christianity".

Furthermore, this doctrine of the Bible laid a foundation for the doctrines, especially the two most important beliefs of the TJC: its identity as the only true church and its rites as the exclusive approach to obtain salvation.

\section{The Bible and the Only True Church}

Due to its belief that it was the only true church with a mission to correct all the other churches, the TJC developed an ecclesiological theory supported by biblical interpretations. The hermeneutics of the TJC can be described as "church-centered hermeneutics" since the main purpose of their biblical interpretation was to establish the authority of the Church. I will demonstrate this from three perspectives: the TJC in the salvation history, the name of the Church, and the "true" church.

\subsection{The TJC in the Salvation History}

For the TJC, one of the most important pieces of evidence proving the claim that the TJC was the only true church was that the Church's emergence fulfilled biblical prophecies. Although the restorationist concept of "early rain and latter rain" was invented by western Pentecostals, the TJC developed a "four ages of church history" theory that is marked by its unique argumentation.

The first age was an "early rain church", that is, a primitive church built after the Holy Spirit's coming at Pentecost. The second age began from 257 AD, when "the rain stopped and the early rain would not fall anymore", which indicated that all the churches had distorted Jesus' teachings, and the Holy Spirit had stopped working. The leaders asserted that by 257 AD, the "Roman Pope was in power" (Jiang 1950b, p. 43) and that "the disciples of the apostles were all dead and various heresies prevailed. Especially Constantine, who killed 50 million saints, exercised his authority, and (the church) became Satan's headquarters" (Wei 1948, p. 6). This era lasted for 1260 years, following the two prophecies in Revelation that "two witnesses will prophesy for 1260 days, clothed in sackcloth (Revelation 11:3)" and that "the woman fled into the wilderness to a place prepared for her by God, where she might be taken care of for 1260 days" (Rev. 12:6). Both of these verses contain the mysterious number 1260, which indicates 1260 years, since one day can also refer to one year. During these 1260 years, all the churches were corrupted, "cheating people with the Bible". Jiang Yuehan noted that the witnesses who would prophesy for 1260 days clothed in sackcloth in Revelation were false prophets since "the meaning of sackcloth was cheating (Zechariah 13, Genesis 27:18-23)" (Jiang 1950b, p. 44). It might be difficult to understand the connection between sackcloth and "cheating", so Jiang provided references. Zechariah 13:4 mentions "putting on a prophet's garment of hair in order to deceive". In Genesis 27:18-23, Jacob covered his hands with goatskins to cheat his father Isaac. From these biblical texts, he concluded that "1260 days" meant "cheating".

Beginning in 257 AD, the Holy Spirit stopped working for 1260 years; naturally, these numbers add up to 1517, the year in which Martin Luther's Reformation began, which initiated the third age. Luther's Reformation, however, was not the true correction of the Christian church, but rather "old wine in a new bottle" (Jiang 1950b, p. 44). After another 400 years, the time that the Israelites were slaves in Egypt (implying that the Christian church remained a slave in Egypt after the Reformation), the TJC was founded in 1917, marking the beginning of the fourth age. Not until 1917, when Wei Baoluo founded the TJC, which was "the spring rain (latter rain) church in the last days", did the Holy Spirit come back: "Only the TJC is the spring rain (latter rain) Holy Spirit church in the last days (Zechariah 10:1), equal to the early rain Holy Spirit church of apostolic times (Joel 2:23)" (Yao 1947, p. AZ8). Jiang Yuehan asserted that the fact that Wei founded the TJC in 1917 was not an accident since the TJC was founded "during the First World War, and because of the emergence of the true church, the war soon ended (Revelation 7:1-3)" (Jiang 1950b, p. 20).

It is obvious, however, that the TJC's view that $257 \mathrm{AD}$ marks "the rise of the Roman Catholic Church" does not make sense. In $257 \mathrm{AD}$, the church was suffering persecution from the Roman 
government, and Pope Sixtus II was martyred in 258 AD. The year of 257 AD is obviously the result of a calculation that must include 1917, 1517, and the mysterious number "1260".

The TJC called this theory the dogma of the "four wives". These "four wives" refer to Jacob's four wives in Genesis: Leah, Bilhah, Zilpah, and Rachel, signifying four separated ages in church history. Leah is Jacob's official wife, and Rachel is his beloved, whereas Bilhah and Zilpah are just maids. Leah represents the church in apostolic times, and Rachel is the TJC. Bilhah and Zilpah, however, refer to the corruption of the Christian church throughout history: Bilhah is the "adulteress", representing the Roman Catholic Church and other Protestant churches; Zilpah is the "widow", referring to the Seventh Day Adventists, who have no husband, that is, the Holy Spirit. The "four wives" doctrine was listed in the "Twelve Fundamental Dogmas", and Wei Yisa noted that "anyone who teaches church history and typology must study the deep meaning of this theory in detail in order to obtain complete salvation" (Wei 1947c, p. B3).

The place where the TJC was founded, northern China, indicated that all the biblical prophecies about the "Orient" referred to Wei Baoluo and the TJC:

1. The true God had set the Garden of Eden in the east, which is a type (yubiao预表) for the present-day church. 2. He will bring his children from the east (Isaiah 43:5) and train his people in the east. 3. There is a prophecy that reads "From the east, I summon a bird of prey" (Isaiah 46:8-11), which is a type for spiritual saints. 4. Only the Magi from the east saw the star of the Lord at first (Matthew 2:11), implying that we, the eastern people, will first seek the Lord. 5. The eastern people first give glory to God and exalt the name of the True Jesus (Isaiah 24:15), and only eastern people are willing to come first. (Jiang 1950b, p. 19)

In addition, the TJC also had the mission to "spread the truth to western countries in turn" (Yu 1948, p. 9), based on the verse predicting that "the Mount of Olives will be split in two from east to west" in Zechariah 14:4.

In a word, the TJC was convinced that the time and the place of its emergence fulfilled the biblical prophecy, indicating that the Church was the only true church founded by God, just as Wei Baoluo had proclaimed.

\subsection{The Name of the Church}

The TJC stressed the significance of the "name" of the church and was convinced that the "True Jesus Church", a name obtained directly from God, signified that the Church exalted the name of Jesus and glorified him alone.

The "name" of the TJC has a close affinity with Chinese culture. The Chinese character "ming" (名) can refer to both "name" and "status". In the Analects of Confucius, there is a well-known saying: "If names are not rectified, then speech will not function properly, and if speech does not function properly, then undertakings will not succeed" (Confucius 2007, p. 88). In Confucianism, names came from the holy monarch in ancient times, manifesting a social and political order reinforced by strict rituals and a musical system. A "name" also contains the moral requirement that a person's behaviors must be in conformity with his/her name or status. The name is "the basic issue ... related to the formation and confirmation of the order of the world rather than a language topic" (Liu 2018, p. 73). In popular culture, Chinese people believe that a good name will bring good luck and fortune to a person or a group. Although the determination to use this name was accidental ${ }^{1}$, Wei Baoluo was convinced that the name of the TJC was obtained from God.

1 The Church had several names at the beginning, and "True Jesus Church" was one of them. In Tianjin, Wei asked Wang Bide (Peter Wang) to write "Jesus' True Church" (yesu zhen jiaohui 耶稣真教会) on a banner for the church. Wang reversed the order of "True" (zhen 真) and "Jesus", and Wei was convinced that it had been revealed by God and decided to use it as the permanent name for the Church (1936, p. 93). 
The leaders of the TJC also criticized other churches' names, such as the name of the London Missionary Society, the Chinese Inland Mission, and the Presbyterian Church, maintaining that they were strange and unreasonable: "We Chinese people cannot figure out the meanings of these names" (Guo 1947a, p. B12). These names were regarded as glorifying themselves rather than Jesus, thereby creating divisions between churches. Instead, the TJC “has the right name and legitimate words (名正 言顺)" (Guo 1947a, p. B12). Inouye concluded that one factor in the success of the TJC was "astute attention to the subtle nuances of the Chinese language" (Inouye 2018a, p. 109).

Furthermore, the leaders of the TJC developed a theory of "naming" to prove its authority. They were convinced that all the biblical verses that contained "the name of Jesus" and "the name of the Lord" signified the name of the TJC. For instance, in Acts 4:12, Peter said: "Salvation is found in no one else for there is no other name under heaven given to mankind by which we must be saved." Although "no other name" refers to the name of Jesus in the text, the author Yu Zaichuan (余再传) asserted that "we cannot be saved in the hundreds of churches under heaven; only believe in the True Church as a pure virgin generated in China where, like Nazareth, we can be regenerated and saved" (Yu 1948, p. 9).

In a catechism of the TJC, the author Jiang Yuehan connected the verse in John 20:31b ("by believing you may have life in his name") to the name of his church. This catechism also includes a rebuttal: "It is obvious that this verse is to persuade people to believe in Jesus; it does not mention that by believing in your church people will have life." Jiang answered that "the church is generated from the biblical promise (Hebrews 10:7), and the Lord will shepherd his sheep by himself (John 10:16)" (Jiang 1950b, p. 6). This reply, however, does not appear to answer the question. Jiang also rewrote the verse in John 1:12 to "yet to all who received him-the true Jesus, to those who believed in his name- the True Jesus Church, he gave the right to become children of God" (Jiang 1950b, p. 7). In the Old Testament, the "name of the Lord" was also viewed as a prophecy of the TJC. Yu Zaichuan noted that "the amazing new name, True Jesus Church, is not from humans, but rather from the amazing inspiration of God, and it corresponds with the Bible. It is written in the Bible: 'my name is too wonderful!' (Judges 13:13-18) (Isaiah 9:6) 'You shall be called by a new name that the mouth of the Lord will give (Isaiah 62:2)'” (Yu 1948, p. 9). In this paragraph, Yu mentions three verses: The first describes how God answered Manoah and told him that his name was Wonderful. The second one is the famous verse, "for to us a child is born... he will be called Wonderful, Counselor", which refers to the name of the child. The "you" in the third verse is the nation of Israel based on its literal meaning. Therefore, no matter to whom the names were attributed in the text, they all referred to the name of the True Jesus Church.

By including "Jesus" in its name, which meant that it was founded in the name of Jesus, the TJC regarded all the biblical verses about "the name of the Lord" and "the name of Jesus" as predictions of itself.

\subsection{The "True" Church}

"True" (zhen 真) was also a key word in the name of the Church, and a theological exegesis based on the character "true" was also derived from the Bible by the TJC. The leaders added the word "true" in front of "God" in the biblical text to make it "true God" and interpreted all the biblical verses containing "true" as referring to the TJC itself. Jesus's claim that "I am the true vine, and my Father is the gardener" in John 15:1 means that "my church is the true church, and you should know that this church is not founded by human hands, but rather is fostered by the Holy Father" (Jiang 1950b, p. 11). Similarly, in the verse referring to the one "who serves in the sanctuary, the true tabernacle set up by the Lord, not by a mere human being" (Heb. 8:2), the true tabernacle also signifies the TJC.

In order to prove that the TJC was "true", the leaders also oriented all the biblical passages on the "true church" towards their church, and all the passages on "false prophets, false teachers, heresy" towards other churches. The TJC was convinced that all the positive metaphors and descriptions in the Bible could be applied to itself. Wei Yisa wrote that: 
The True Jesus Church is the true vine that produces good fruits, the Son of Man walking in the midst of the lampstands... It is the fulfillment of the prophecy of re-exodus and the headman rebuilding the Holy city and the sanctuary. She is the holy woman wearing a crown of twelve stars, the capable wife with spiritual gifts and virtue, the well-dressed bride who obeys the twelve doctrines, the mother of all humans who was born from the second Adam and would not be seduced, the wife who shares the spiritual promise, the chosen queen who cleans herself with myrrh oil, the bride who clings to her bridegroom, the angel who is worthy to hold the seal, reaping from the east, the bride of the Lamb... She is the appearance of the ark of the covenant, the era of casting the net from the Most Holy Place, the vision of the New Jerusalem, the family of the living God, the pillar of the truth of the world, the mountain that fills the whole earth and leads all the people to return, the clever virgin who has the name of the eldest son, being raised in the first resurrection, the small group with the name of the true God and Jesus, the master who bears the future world, the spiritual group who sings Amen and Hallelujah. (Wei 1947c, p. B14)

It is not difficult to spot the many biblical quotations and allusions in this paragraph. Some phrases originally described Jesus, such as the "true vine" and "the Son of Man"; some describe the church, such as "the bride of the Lamb" and "the family of the living God"; some are images from apocalyptic literature, such as the "woman wearing a crown of twelve-stars" from Revelation, and "the mountain filling the whole earth" from Daniel; some are from the historical books of the Old Testament; and some are combinations of several figures. For instance, "the eldest son" refers to Jacob, "the first resurrection" refers to Jesus, and the "smart virgin" is from Jesus' parable (Matthew 25:1). Wei Yisa combines these elements together. The "era of casting a net from the Most Holy Place" is a confusing combination of two irrelevant concepts.

They also denounced other churches using the Bible. Jiang asserted of other churches that "their teachings and behaviors were all different from Jesus' and the apostles'" (Jiang 1950b, p. 99), based on Galatians 1:6-10. In this passage, Paul notes that some Jewish Christians forced Gentile believers to follow Jewish laws, which are "a different gospel". Jiang also wrote that "the pastors and missionaries cross sea and land to make a single convert, and they make the new convert twice as much a child of hell as themselves" (Jiang 1950b, p. 103). He quoted the verse in Matthew 23:15 in which Jesus denounced Scribes and Pharisees to denounce all other churches. Guo Duoma (Thomas Guo 郭多 马), a church leader, noted that "wherever our church is proclaimed, the chosen people will go out of Babylon, (Babylon refers to all the modern churches that have become the devil). They hear the voice from heaven, 'come out of her, my people, so that you do not take part in her sins, and so that you do not share in her plagues' (Rev. 18:4)" (Guo 1947a, p. B12). For him, all the other churches were the Babylon of Revelation and would be punished, which is why the TJC must "correct" them.

Overall, the TJC developed a series of theories in defense of its identity as the only true church.

\section{The Bible and the True Rites}

Wei Baoluo and the other founders formulated strict stipulations for joining the Church: baptism of the Holy Spirit marked by speaking in tongues, facedown immersion baptism in flowing water in the name of Jesus, a foot-washing ritual, Sabbath-keeping, and so on. The TJC was convinced that these rituals, as essential requirements for salvation, strictly adhered to biblical teachings. The TJC was also convinced that other churches, "although they (other churches) used the Bible, they did not follow the biblical teachings (Amos 8:5)" (Jiang 1950b, p. 103); because of their rejection of these rituals, they could not obtain true salvation. Inouye noted that three factors, namely Berntsen, the biblical text, and a Confucian concern, had an impact on the ritual view of the TJC, which depended on "the underlying assumption that the cosmos is governed by certain constant laws and forces which are responsive to human action correctly performing a ritual" (Inouye 2018b, p. 67).

When Wei Baoluo founded his church, he stressed that baptism must be done "facedown" (leaning forward rather than laying back into the water) and immersive. Wei recalled that "I tried a lot of ways 
to get rid of my sins, but I could not ... I prayed day and night and begged God, confessing my sins and repenting; I cried bitterly to God but I could not leave sins behind for many years". This changed after he was baptized facedown. After his facedown baptism in 1917, Wei claimed that "I had seen the glorified Lord Jesus appearing to me ... and I can speak in tongues and translate them, being filled with the Holy Spirit" (Wei 1947b, p. B17). The practice of facedown baptism first came into existence through Wei's personal experience. Subsequently, the Church established facedown immersion as the standard mode of baptism, which it called the "legitimate baptism in flowing water" (hefa da shuixi 合 法大水洗), insisting on facedown immersion into flowing water in the name of Jesus instead of the Father, Son, and the Holy Spirit.

Being convinced that facedown baptism was inspired by the Bible, the leaders of the TJC wrote many articles to explain it. They objected to sprinkling baptism based on the narratives of the Old Testament. Jiang Yuehan argued that baptism was "the antitype (yubiao 预表) of the Israelites crossing the Red Sea", since Paul argued that the Israelites passing through the Red Sea "were baptized into Moses in the cloud and in the sea" (1 Corinthians 10:1-2). Therefore, "people who were baptized into Moses have the evidence of passing through the Red Sea. Anyone who converts to Jesus must receive 'legitimate baptism' as the evidence of their conversion" (Jiang 1950a, p. 15). Jiang also noted that all the biblical texts concerning the Israelites passing through the Red Sea (such as "the Lord made a way through the sea") refer to a form of baptism. All the churches that practiced a sprinkling form of baptism were the same as the Egyptian Pharaoh who resisted the Israelites: "Their baptism was the same as the Egyptians passing through the Red Sea without faith, swallowed up by the water in the end" (Jiang 1950a, p. 15). Similarly, Noah's Ark "was the type (yubiao 预表) of the church, the only church, created in the end and alone saved, the Ark delivering the people out of death" (Jiang 1950a, p. 18). The ark passed through the water, which signifies immersion baptism. The fact that there was only one ark indicates that there is only one method of legitimate and effective baptism.

The view that sprinkling baptism was un-biblical was common among Chinese Protestant Christians; for the TJC, however, being baptized in a pool was also incorrect. The place of Jesus' baptism, the Jordan River, was obviously a flowing river, and there was no other record of anyone having been baptized in a pool: "There is no such way in Scripture, which is our standard. Since the Bible does not record it, although some people regard it as the best, correct and simple way (Proverbs 14:12), we do not dare to do this since it runs ahead of the teachings of Christ" (Jiang 1950a, p. 21). In addition, according to their interpretation of Jeremiah 2:13, the leaders believed that God abhorred being baptized in a pool, since he accused people who had "forsaken the spring of living water that the Lord has sent, instead of digging out broken cisterns for themselves. It is a great evil against God's commandment" (Jiang 1950a, p. 21). The "cistern" in Jeremiah was identified as the pool used in other churches' baptisms.

For the TJC, facedown baptism also had biblical roots. The foremost reason for facedown baptism was that baptism symbolized being baptized into Jesus' death: "For the Lord was crucified for us... when he was dead, he 'bowed his head' which left us a precious model to follow" (Jiang 1950a, p. 22). For them, the meaning of baptism was to follow Jesus' death, and the bowing of his head was the image - the icon—of Jesus' death; facedown baptism replicated the image of Jesus' death. Any other form of baptism practiced by other churches that used faceup baptism involved "changing the original truth to a false way following human will" (Jiang 1950a, p. 22). This type of baptism "follows the death of human beings" (Jiang 1950a, p. 27), since humans usually lie down with their face up when they are dead. Being made conformable unto Jesus' death meant not only following Jesus' spirit, but also following his image. They also argued that the Israelites must have bowed their heads when they passed through the Red Sea and that "Noah could not have walked into the ark with his head raised (Gen. 6:14-16), and that the high priest entered the sanctuary bowing his head (Heb. 9:7-10)."

In addition, the legitimate baptism must be performed in the name of Jesus instead of "in the name of the Father, the Son, and Holy Spirit", which is an obvious departure from the biblical text. 
The TJC claimed that the name of the Father, Son, and Holy Spirit was not the name of God but rather his position and that the true name of God is Jesus.

The TJC's other two rituals, foot-washing and Sabbath-keeping, also had biblical foundations. Foot-washing, originating from the Gospel narrative in which Jesus washes the feet of his disciples after the Last Supper, was regarded as one of the necessities for salvation by the TJC, since Jesus told Peter that "unless I wash you, you have no share with me" (John 13:8). After being baptized, believers of the TJC had to receive a foot-washing ritual in order to be cleansed and saved. The TJC advocated that Christians should keep the Sabbath, and any church that did not observe the Sabbath were "adulteresses" since they followed the rules of the world and abandoned biblical teachings. The TJC, however, did not accept the Seventh Day Adventist church, because "it does not have the Holy Spirit, just as a wife who does not have a husband, and so it is a widow (Lamentations 5:5)" (Jiang 1950b, p. 99). Only the TJC had the gift of the Holy Spirit and kept the Sabbath; thus, the TJC was the only true bride of Christ. Communion, the baptism of the Holy Spirit, and tongue-speaking were also important doctrines and rituals; because they are similar to the doctrines of other Pentecostal churches, therefore, I will not elaborate on them.

According to these biblical interpretive examples, I will summarize the interpretive approaches of the TJC. Literal interpretation was the main approach, which is known as an "ahistorical literalistic" (Archer 2005, p. 94) approach, in which the interpreters ignore the historical dimension of Scripture and are convinced that all the biblical events recorded in the New Testament can reoccur in the present time: "The Bible is the Word of God and understood at face value. The horizons of past and present were fused, or from a critical perspective, confused" (Archer 2013, p. 133). This is how the theologians of the TJC interpreted their miraculous signs. Asserting the necessity of foot-washing, being baptized in flowing water, and connecting all the passages on the "East" to China also reflect the TJC's literalistic methods. However, in contrast to the early western Pentecostals, such as Charles Parham and William Seymour, who focused on Spiritual baptism and oneness Pentecostalism (Archer 2005, p. 102), the interpreters of the TJC also used other methods to prove its unique doctrines.

Another approach was allegorical interpretation, such as the "four wives" theory, and other interpretations based on the Old Testament. The interpreters established an allegorical connection between theological themes and the biblical text, especially passages in the Old Testament from which it was difficult to extract Christian teachings through a literal method. The interpreters of the TJC, however, usually called the allegorical interpretations and their interpretations of prophecies "typology". The first reason for this nomenclature stems from the Chinese language, since "typology" in Chinese is translated to "yubiao (预表)", which sounds similar to "prediction" (yuyan 预言), as both of these words contain " $y u$ " (预). The literal meaning of "yubiao" involves using "pre-indicate" as a verb or "pre-indication" as a noun, which is easily to be confused with the "typology".

More importantly, the Chinese interpreters of this period, both Fundamentalists and Pentecostals, did not like the word "allegory", which implied that the interpretation was created by humans and seemed likely to weaken its authority. They usually used the terms "typology" or "spiritual interpretation" in order to underscore that the interpretation was based on the revelation of the Holy Spirit. Many Fundamentalist theologians, such as Watchman Nee (Ni Tuosheng 倪柝声), who tended to use allegorical interpretations, called their methods "spiritual interpretation" since "only can God interpret his word ... we should understand God's word and obtain the interpretation from the Holy Spirit" (Nee 1996, pp. 88-89). Both of these groups highlighted the function of the Holy Spirit in the biblical interpretation, which was also an effective way to eliminate foreign theological authority in biblical interpretation.

The interpreters of the TJC also drew some specific connections between two verses that contained the same word, which was how they determined the number "1260" to mean "cheating". This strategy, called "Scripture interpreting Scripture", was also frequently used by Fundamentalists, such as John Sung (Song Shangjie 宋尚节), who typically connected different passages together and summarized a 
"spiritual meaning" that was regarded as coming from the Holy Spirit: "When I was studying this book, in my prayer, the Holy Spirit revealed to me how to interpret it by ... " (Sung 1990, p. 292).

The interpretive methods used by the TJC were similar to those used by Fundamentalist interpreters, since the two communities of faith both stressed biblical authority and claimed that all of their doctrines conformed to the Bible. Russell Spitter noted that "If the word Fundamentalism gets defined only by biblical style, Pentecostals can be labeled Fundamentalists without question" (Archer 2005, p. 90). According to the studies of the TJC, however, the purposes and theological beliefs of the TJC were distinct from those of Fundamentalists. The theology of Fundamentalists was Christ-centered; whatever approaches they used sought to prove that all the biblical verses pointed toward the salvation of Christ and practical teachings for the believers' lives. The TJC's interpretation was church-centered in the defense of existing doctrines. These different hermeneutical purposes differentiate these two groups.

\section{Conclusions}

Absorbing western Pentecostal traditions, the TJC developed unique doctrines in the context of Chinese society during the Republican era; these doctrines have persisted down to the present. This study examines the role of the Bible in the formation of the TJC's theological system and in the defense of its authority. I will briefly summarize this from three main perspectives.

First, the TJC viewed itself as part of the biblical narrative, inserting itself into the biblical experience and history. As we mentioned, the connection between lived experience and the biblical narrative was the main reason for the development of the Pentecostal movement. The TJC viewed its charismatic experience as the reoccurrence of the signs of Apostolic times, so the church traced its tradition and authority directly from Scripture, rather than from any western theological tradition. Wei Baoluo viewed himself as the equivalent of a biblical prophet who had received a direct revelation from God, claiming that the Holy Spirit had commissioned him to point out and correct what he decried as grave doctrinal errors among Christian leaders around the world (Wei 1947a, p. F2). The successors of Wei Baoluo further propagated this narrative of the TJC as the only true church predicted in the Bible that fulfilled all the biblical prophesies. The TJC respected the Bible as a supreme authority above all other traditions and also saw itself as a living continuation of the biblical narrative in an elevated position above all other churches. Interpreting itself as part of the divine narrative continuing to play out during the present-day lent gave the TJC a strong collective identity and a sacred purpose.

Second, the Bible proved the TJC's unique doctrines. As previously discussed, the TJC developed two innovative doctrines: one relating to its status as the one true church and another surrounding its rites for exclusive salvation, through which it formed its own denominational tradition. These two doctrines set the TJC apart from other Pentecostal churches, such as Berntsen's Apostolic Faith Church or the Jesus Family (yesu jiating 耶稣家庭), which was founded by another charismatic leader, Jing Dianying (敬奠瀛), and which shared similar charismatic experiences, or from the Fundamentalist churches, which shared a similar position regarding biblical interpretation. The establishment of these two doctrines, however, cannot be separated from the TJC's church-centered hermeneutics and its leaders' detailed interpretations.

Third, the Bible played a role in shaping the identity of the TJC as an indigenous Christian church. The TJC was explicitly not merely a Chinese transplant of a North American Pentecostal church but an indigenous Chinese church. Its development as a culturally and nationally independent church relates not only to the fact that is was founded and led by Chinese Christians but also stems from its deliberate connection with a Chinese social ethos; in particular, the kind of nationalism popular at the time and its strong identification with Chinese culture. Biblical interpretation played a significant role in shaping the TJC's identity as a Chinese church, a fact that has not been sufficiently discussed in other studies. Lian's studies (Lian 2008) have discussed the importance of nationalism in shaping an indigenous church. However, these studies fail to examine the theological roots of these developments, especially the formative role played by biblical theology. Inouye pointed out that appealing to the Bible was an effective method "because of the special reverence given to written scripture texts" (Inouye 2016, 
p. 903), which was not sufficient to appreciate the significance of its hermeneutics. Through its unique biblical interpretations, the TJC was able to claim that the restorationism of the "latter rain" prophecy was fulfilled in China and that the only true church had emerged in the East. Inouye described how the TJC subtly utilized the "True Jesus Church" as a straightforward name to emphasize its purity (Inouye 2018a, p. 110). In this study, however, we can see that the TJC also utilized traditional Chinese thoughts on the concept of "name" to indicate its legitimacy; furthermore, TJC leaders identified the name of the TJC with the name of Jesus through a series of complex hermeneutical maneuvers.

Although the biblical interpretations of the TJC have many shortcomings and have yielded some farfetched conclusions, they were a significant factor in the TJC's success in becoming one of the largest independent denominations of the Republican era. Furthermore, as one of the most formative components of Christian faith in any era, the Bible's role in the development of other Chinese Christian churches and traditions during this period deserves further study.

Funding: This research was funded by Humanities and Social Sciences Youth Foundation of Ministry of Education of China “The Sinicization of Chinese Fundamentalism in Republican China” (民国时期基督教基要派的中国化研 究), grant number: 18YJC730008.

Conflicts of Interest: The author declares no conflict of interest.

\section{References}

Anonymous. 1936. Zhen yesu jiaohui zongbu shizhounian jinian zhuankan 真耶稣总部十周年纪念专刊 (Tenth Year Anniversary Commemorative Volume of the General Headquarters of the True Jesus Church). Shanghai: True Jesus Church.

Anonymous. 1997. Hubei Local Chronicles: Religions. Wuhan: Hebei People Public.

Archer, Kenneth J. 2005. A Pentecostal Hermeneutics: Spirit, Scripture and Community. Cleveland: CPT Press.

Archer, Kenneth J. 2013. Pentecostal Hermeneutics: Retrospect and Prospect. In Pentecostal Hermeneutics: A Reader. Boston: Brill, p. 133.

Confucius. 2007. The Analects of Confucius. Translated by Burton Watson. New York: Columbia University Press.

Guo, Duoma. 1947a. Zhen yesu jiaohui de mingcheng ruhe 真耶稣教会的名称如何 (The Meaning of the Name of the True Jesus Church). In True Jesus Thirtieth Anniversary Commemorative Volume. Nanjing: True Jesus Church, p. B12.

Guo, Ziyan. 1947b. Yanjiu zhendao yingyou de taidu 研究真道应有的态度 (The Correct Attitude for Studying the Truth). In True Jesus Thirtieth Anniversary Commemorative Volume. Nanjing: True Jesus Church, p. B2.

Inouye, Melissa Wei-Tsing. 2016. Miraculous Modernity: Chrismatic Traditions and Trajectories within Chinese Protestant Christianity. In Modern Chinese Religion II 1850-2015. Edited by Jan Kiely Vincent Goossaert and John Lagerwey. Boston: Brill, pp. 885-919.

Inouye, Melissa Wei-Tsing. 2018a. China and the True Jesus: Charisma and Origanization in a Chinese Christian Church. New York: Oxford University Press.

Inouye, Melissa Wei-Tsing. 2018b. Signs of Power: Christians' Search for Certainty in Troubled Times(1906-1919). In The Church as safe haven: Christian Governance in China. Edited by Joseph Tse Hei Lee and Lars Peter Laamann. Boston: Brill, pp. 49-70.

Jiang, Yuehan. 1950a. Hefa dashuixi 合法大水洗 (The Legitimate Baptism in Flowing Water). Nanjing: True Jesus Church.

Jiang, Yuehan. 1950b. Zhenli jianyao wenda 真理简要问答 (Catechism). Nanjing: True Jesus Church.

Lian, Xi. 2008. A Messianic Delieverance for Post-Dynastic China: The Launch of the True Jesus Church in the Early Twentieth Century. Modern China, 407-41. [CrossRef]

Liu, Shiyu. 2018. Name and Order: An Introduction to Pre-Qin Confucian Ideas of Name and Status. Journal of Peking University 55: 73-81.

Nee, Watchman. 1996. Shen huayu de zhishi 神话语的执事 (The Normal Christian Preacher). Hong Kong: Christian Publishers.

Oliverio, L.William. 2012. Theological Hermeneutics in the Classical Pentecostal Tradition: A Typological Account. Leiden: Brill. 
Sung, John. 1990. Jiang jing ji 讲经集 (Bible Study: Old Testament Book1). Hong Kong: The Bellman House Publishers.

Wacker, Grant. 2001. Heaven Below: Early Pentecostals and American Culture. Cambridge: Harward University Press. Wei, Baoluo. 1947a. Wanguo gengzheng bao 万国更正报 (Global Church Correction). In True Jesus Thirtieth Anniversary Commemorative Volume. Nanjing: True Jesus Church, p. F2.

Wei, Baoluo. 1947b. Lingjie dazhan wei baoluo kao shengling lun 灵界大战魏保罗靠圣灵论 (Wei Baoluo Fighting against the Devil through the Holy Spirit). In True Jesus Thirtieth Anniversary Commemorative Volume. Nanjing: True Jesus Church, p. B18.

Wei, Yisa. 1947c. Zhenyesu jiaohui sanian jinian zhuankan 真耶稣教会卅年纪念专刊 (True Jesus Thirtieth Anniversary Commemorative Volume). Nanjing: True Jesus Church.

Wei, Yisa. 1948. Yage zhengyi 雅歌正意 (Song of Songs Commentary). Zhenyesu jiaohui shenglingbao 真耶稣教会圣 灵报 (The True Jesus Church Holy Spirit Times) 2: 6.

Yao, Jiannan. 1947. Zhengming zhen yesu jiaohui weizhen 证明真耶稣教会为真 (Testifying the True Jesus Church to be True). In True Jesus Thirtieth Anniversary Commemorative Volume. Nanjing: True Jesus Church, p. AZ8.

Yu, Zaichuan. 1948. Qimiao de ming 奇妙的名 (The Wonderful Name). Zhenyesu jiaohui shenglingbao 真耶稣教会 圣灵报 (The True Jesus Church Holy Spirit Times) 1: 9.

(C) 2020 by the author. Licensee MDPI, Basel, Switzerland. This article is an open access article distributed under the terms and conditions of the Creative Commons Attribution (CC BY) license (http://creativecommons.org/licenses/by/4.0/). 